\title{
"The Dude Abides": How The Big Lebowski Bowled Its Way from a Box Office Bomb to Nation-Wide Fests
}

\section{ABSTRACT}

Since Blood Simple, the first film they wrote and directed together, the Coen Brothers have been working their way up in the film world and, in spite of their outside-the-mainstream taste for the noir and the surreal, have earned a number of prestigious prizes. After Fargo, one of their most critically acclaimed films, expectations were high, and when the Brothers released their next bizarre venture, most critics rushed to measure it against Fargo's success. Consequently, The Big Leboreski, the Coens' 1998 neo-noir detective comedy, was considered an incoherent, "unsatisfactory" medley of genres and styles and a box office bomb, and nothing hinted that this unorthodox story of mistaken identity, featuring a pot-smoking, unemployed character named the Dude as its "hee-ro," would gain a following. Yet, since its 1998 DVD release, The Big Lebowski has been hailed as the first cult film of the Internet, continuously inspiring versatile cultural phenomena as nonconformist in their nature as the movie itself. This essay examines particular factors which initially might have been responsible for alienating the audience only to help The Big Leboreski become a peculiar cultural event in later years. It looks at The Big Lebowski's characters, the historical time and place of the film's action as well as at various external historical events, phenomena, places and people such as, for example, the Port Huron Statement, the Reagan-Bush era, Los Angeles and its immigration issues, racial minorities, civil rights activists, the Western genre and, last but not least, Arnold Schwarzenegger. Reflecting the film's oddities, this bag of cultural idiosyncrasies appears to provide some plausible explanations for The Big Leboreski's unexpected, against-all-odds rise from the marginal position of a critical and commercial failure to the status of a cult classic and cultural landmark. 
There is no accounting for taste. Specifically, there is no accounting for the public's taste when it comes to art, especially in a country where possibly every other nation in the world is bound to have a representative. Of course, given the right time and place, taste can change, providing an opportunity for yet another from-rags-to-riches story in which a commercial failure rises to a cult classic and a cultural phenomenon of unexpected proportions. In 1998, the Coen Brothers' neo-noir detective comedy The Big Leboreski $i^{1}$ failed the taste not only of the average American, but also of the Sundance Film Festival audience and critics who rated the movie with quite a few walkouts (cf. Howell). An unnamed British reviewer in The Guardian branded TBL as "an unsatisfactory film," trading "the tautness that won Fargo such acclaim for a loose, meandering outline" ("Big"). The same anonymous author doomed the film by calling it "infuriating" and prophesying that it "will win no prizes" ("Big”). Due to a different cultural sensibility and, possibly, the specific sense of humour famously attributed to the Small Island, the British fortune-teller-turned-critic might be essentially forgiven for disregarding the movie's potential which, with time, would meander way ahead of Fargo in public acclaim. Yet, some natives of the Big Country were equally unenthusiastic, regardless of which part of the US they came from. The New York Daily Nerws movie critic Dave Kehr hybrid-titled his review “Coen Brothers' Latest Is a Big Letdownski Comedy about Druggie Bowler Strikes Out and Its Tired Film Noir Plot Is a Turkey" (Kehr), and as if this lexical and stylistic abuse was not atrocious enough, Kehr tautologizes by berating the Coens for dropping their main character "in the middle of one of their standard film noir plots, a vein they've been vigorously overworking from Blood Simple to Fargo," and for "ask [ing] him to behave like a professional crime-stopper" (Kehr). According to Kehr, the Coens' story is "a tired idea, and it produces an episodic, unstrung film.”

Many other reviewers have deemed the movie's alleged lack of "tautness" in narrative and cinematic style to be an almost unforgivable sin, branding TBL as "a bunch of ideas shovelled into a bag and allowed to spill out at random" ("Big"), "the Coens' gaudy bag of tricks, whose cleverness and imagination exist mainly for their own sake" (Rosenbaum), or a narrative in which "the story line is in truth disjointed, incoherent and

1 Instead of the full title, the abbreviation $T B L$ will be used in most cases throughout the essay. Also, all the quotations from the film will be parenthetically cited with the abbreviation $T B L$, with three exceptions where, in order to preserve the characteristic spelling of some words, two block quotations and one action description are provided from the printed screenplay and accordingly indicated. 
even irritating” (Turran). Certainly, as Fred Ashe more recently and less aggressively points out, $T B L$ defies "the constraints of literary form by stitching together a variety of genres: the noir detective story ...., the Busby Berkeley musical, the Vietnam movie, the pornographic movie, the screwball comedy, the buddy film, and the 1960s romantic quest à la Easy Rider" (55). Such "stitching together" may be a challenge for the storyline, and yet, Pulp Fiction or Clerks, both released four years prior to TBL, were spectacular successes, although neither of these two culturally significant phenomena can boast a particularly linear or coherent narrative. Also, even if $T B L$ mixes genres and exhibits an arbitrary narrative technique, the story is not emotionally draining in a heavy postmodern way in which, for instance, Gilliam's 1998 adaptation of Thompson's Fear and Loathing in Las Vegas may appear to be to some viewers. Thus, the critical complaints about the movie's stylistic and narrative incoherence hardly seem a legitimate reason for TBL's initial lack of public acclaim, especially that, as Roger Ebert observes, the way $T B L$ "rushes in all directions and never ends up anywhere" is not "the film's flaw, but its style," cohering with the lifestyle of the main character:

The Dude, who smokes a lot of pot and guzzles White Russians made with half-and-half, starts every day filled with resolve, but his plans gradually dissolve into a haze of missed opportunities and missed intentions.... The spirit is established right at the outset, when the narrator (Sam Elliott) starts out well enough, but eventually confesses he's lost his train of thought. (Ebert)

One might argue that TBL's unexpected rise from its critically and commercially marginal position to the status of an almost unprecedented cult film in the years following its DVD release stems from the fact that the Coens' creation embodies their "inspired, absurdist taste for weird, peculiar Americana [and] their own bizarre subgenre" (Howe) as well as some more traditional, even if largely revised, American values. TBL is "perhaps the only psychowesternoircheechandchonginvietnambuddy genre pic in existence" (Comentale and Jaffe 3), and, as such, testifies to an outlandish amalgam of individualism and creativity, the two crucial prerequisites of the American way to wealth. The mixture of genres reflects the versatility of American culture and refers to important historical events, while the movie's commercial fate is a postmodern spin on the American Dream myth, in which there is no hero but just the Dude who is "the laziest [man] in Los Angeles County ... which would place him high in the runnin' for laziest worldwide" (TBL). To make some more sense of why this independent, marginal medley of genres, styles and peculiar characters 
alienated the audience at first and then "went out and achieved anyway" $(T B L)$ without following any methods for success, it might be beneficial to examine more closely the essential elements contributing to the creation of any text: the time, the place and the characters. In $T B L$, all these components exhibit some amount of otherness, marginality, and asynchronism with the expectations of the American middle class, the targeted audience of most American movies, while invariably addressing classic elements of US culture.

At the beginning of the movie, the Stranger, the story's cowboy-type frame narrator, announces,

A way out west there was a fella, fella I want to tell you about, fella by the name of Jeff Lebowski. ... This Lebowski, he called himself the Dude. ... Now this story I'm about to unfold took place back in the early nineties-just about the time of our conflict with Sad'm and the Eye-rackies. I only mention it 'cause sometimes there's a man-I won't say a hee-ro, 'cause what's a hee-ro?-but sometimes there's a man ... and I'm talkin' about the Dude here-sometimes there's a man who, wal, he's the man for his time'n place, he fits right in there-and that's the Dude, in Los Angeles. (Coen and Coen 3-4)

Set in the early 1990s, the movie, however, hardly ever refers to the Gulf War, while frequently bringing up the Vietnam War through multiple ramblings of the Dude's bowling pal Walter Sobchak, a Vietnam veteran. Unlike Walter, the Dude is a pacifist, a pot-smoking, laid-back hippie stuck in the 1960s and early 1970s, the heyday of the civil rights movement, when, as he himself claims, he helped to draft the Port Huron Statement (1962) and was one of the members of the Seattle Seven (1970), the two radical student-based anti-war ventures of the New Left. Among its multiple principles defining what was wrong with America of the 1960s and what steps should be taken to amend the warped democracy, the Port $\mathrm{Hu}-$ ron Statement condemned "the pervasiveness of racism in American life," the perils of "the Cold War, symbolized by the presence of the Bomb," and the international "uncontrolled exploitation ... of the earth's physical resources" ("Port Huron"), all of which had been long neglected by the United States government, mostly on account of the country's enduring involvement in the financially exploitive Vietnam War, a frequent reference in the film. The Statement's supporters proclaimed that racism, possible nuclear extinction and environmental disaster "either directly oppressed" them "or rankled [their] consciences and became [their] own subjective concerns," leading them "to see complicated and disturbing paradoxes in [their] surrounding America" as well as the hollowness of the nation's founding declaration that "all men are created equal" and should be able 
to pursue happiness in a war-free country and world ("Port Huron"). Professing "we are a minority," the Port Huron activists knew how important but also how marginal to "the vast majority of ... people" their views at the time were ("Port Huron"). In 1969, replacing the vacuum created by the collapse of the national Students for a Democratic Society, the leaders of the Seattle Liberation Front, founded by University of Washington professor Michael Lerner, were tried and briefly imprisoned after the antiVietnam war demonstration on February 17, 1970 in front of the Federal Courthouse in downtown Seattle ("Seattle").

Based on a real member of the Seattle Seven, the Coens' friend Jeff Dowd, the character of Jeffrey the Dude Lebowski is a retired-civil rights activist, who finds himself at the end of the Reagan-Bush era with his aversion to aggression intact, but with no radical anti-war ventures to fuel his existence. The Persian Gulf War did not last long enough to call for any significant anti-war demonstrations and actually earned the Republican president national support. Although any specific references to the political climate of the country or the L.A. region are absent from the story, in the late 1980s and early 1990s, Los Angeles County, as well as most other regions of Southern California, "remained under the stewardship of a countersubversive coalition that targeted civil rights crusaders, feminists, antiwar demonstrators, and gay activists as culpable for the social ills and economic malaise wrought by economic restructuring, deindustrialization, and the dismantling of the welfare state" (Avila 234). Generally, "[1]iberalism in all its forms was anathema" during the Reagan-Bush administration (Glazer 234). Upon the Dude's visit to claim compensation for his soiled rug, the poser millionaire Lebowski, with whom the Dude is confused at the beginning of the story, also reminds him that the Dude's "revolution is over" and that "the bums will always lose" (TBL). Even in the Dude's own words, he is essentially someone who "the square community does not give a shit about" (TBL).

Such anti-liberal circumstances could hardly make the Dude fit "right in there," and yet, the Dude remains comfortable within the film's historical setting. This laid-back attitude, however, might be what initially encumbered his appeal at the time of the film's release in the late 1990s. In the early 1990s, limiting his protests to professing pacifism, the Dude poses as a mere reminder of the radical New Left individualism which once challenged the government by "opposing the Vietnam War, working for free speech and civil rights, and practicing civil disobedience" (Stacey Thompson 126). Thus, in essence, the Dude was to the protest period of the Vietnam War what Thoreau had been to the imperialistic period of the Mexican-American War, while in the early 1990s, he exemplifies a hippie version of Rip Van Winkle on whom "the changes of states and empires 
made but little impression” (Irving 991). As Fred Ashe points out, both Rip and the Dude lack "masculine aggression" and seem "unfazed" by the respective wars referred to "in both texts [which] come off as inconsequential and serve primarily to highlight the thematic war between aggressive American striving and passive American slacking" (Ashe 48, 49). In 1998, during the second term of Clinton's presidency, the overtly liberal image of an economically unproductive, unburdened and unconcerned hippie, who definitely inhales more than once within 112 minutes of his screen appearance, failed to fit in the country's economically thriving frame, which is to a certain extent surprising, considering the number and popularity of slacker films and television shows released around this time period, such as, for instance, Wayne's World (1992), Beavis and Butt-Head (1993-1997), or Clerks (1994). In Doing Nothing: A History of Loafers, Loungers, Slackers, and Bums in America, Tom Lutz observes that although "many of the slackers of the 1990s and beyond have not felt much power to change the world" the way that the 1950s and 1960s rebels did (299), the 1990s slacker "characters [do] have jobs, just not good jobs" (285). The work-shy Dude, on the other hand, helped move history forward in the 1960s, but, ironically, got stuck there and, thus, has more in common with the loafers of the past, even distant past (e.g. Rip Van Winkle, Bartleby or Huck Finn), than with the 1990s counterculture in which many indolent individuals managed their "disregard for the world of employment [only] very briefly" (Lutz 286), accepting mediocre jobs over total rejection of work. As a result, in 1998, the Dude turned out to be an outsider even in the world of outsiders and, thus, might have seemed a little redundant to the audience. Pondering on what "a Lebowski" is and how the phenomenon exists in the world, the editors of The Year's Work in Lebowski Studies observe,

At first glance, we can reasonably assert that it is not a tool, in the same way, say, a hammer ... or a heavy drink may be a tool. In fact, compared to the familiar things on our domestic shelving units, this one seems to lack any obvious purpose, any implicit use or application to aid either the individual or the community. The actual viewing experience produces nothing, accomplishes nothing, changes nothing. In fact, Lebowskiusers - the "achievers" - use the film to avoid work, and whatever force or energy they might apply in their endeavor is clearly unmatched by any obvious input. (Comentale and Jaffe 3 )

While other cinematic slacker characters might appear equally unproductive in what they have to offer to the viewers, the Dude surpasses all of them in failing to meet any expectations of the audience and society by "reject[ing] such traditional markers of American self-hood as family, career, religion, [and] even his given name" (Ashe 52). In the Rip Van Winkle 
manner, "the Dude drifts through life guided by no personal code more tangible than the desire to live free of care" (Ashe 52), but even in this characteristic he outmatches Irving's protagonist, because the middle-aged Dude has no family to neglect and, therefore, avoids the accusation of being an irresponsible husband and father.

Yet, a couple of years after its 1998 DVD release, The Big Leboreski and the Dude must have benefitted many individuals and more than one community, giving rise to such cultural phenomena as: annual Lebowski Fests, which originated in 2002 in Louisville, Kentucky, and since 2004 have been "replicated ... in other locations: Las Vegas, New York, Los Angeles, Austin, Seattle, London, [and] Edinburgh" (Comentale and Jaffe 23); Dudeism, "a religion deeply inspired by The Big Lebowski, as well as several other traditions that predate Lebowski-most particularly: Taoism, Zen Buddhism, American Transcendentalism and humanism" (Dudeism"); I'm a Leboreski, You're a Lebowski: Life, the Big Leborwsi and What Have You, a 2007 book by the Lebowski Fest organizers, prefaced by the Dude (Jeff Bridges) himself and including interviews with most of the movie's cast; and at least one academic study, The Year's Work in Leboreski Studies, a 2009 insightful collection of essays by scholars referred to in the present Lebowski essay. This, of course, is just the crème de la crème of the Lebowski cult, the beginnings of which "are shrouded in mystery, thriving elsewhere in multiple viewings, late-night campus screenings, recitations of catch-phrases, drinking games, and theme parties" (Comentale and Jaffe 23). In 2007, commenting on the upcoming Lebowski Fest UK in Edinburgh, Liz Hoggard gave TBL its British share of credit by interestingly accentuating the film's bizarre achievement through the recollection of its unsuccessful beginnings:

The plot is frankly unfathomable. The film bombed at the box office. And yet many fans consider the Coen brothers' The Big Leboreski a work of 'cinematic pop poetry,' and Observer readers rate it the seventh funniest film ever. Back in 1998 when it was first released the film was considered a flop, but it has now sold more than 20 million copies on DVD. One Wall Street firm even interviews candidates by throwing lines of the film at them-to see if they can pick up on them.

Establishing oneself on Wall Street via mere linguistic impact is an unquestionable achievement in itself, making one wonder which exchange of lines in particular would result in being hired at that particular firm. The likely winner seems the scene where the millionaire Lebowski asks the less than casually clad Dude (his jelly sandals are a touch of sheer genius), "You don't go out looking for a job dressed like that? On a weekday?" to 
which the Dude responds with a question, "Is this a... what day is this?" $(T B L)$. In hindsight, had $T B L$ been released in 2002, the film might have been received with much more enthusiasm. In spite of its apparent lack of social and cultural commentary or usefulness, TBL can be experienced as a healthy cultural balance to the American obsession with measuring one's life through economic success and the trite US policy of manifest destiny. In the prosperous late 1990s, however, few felt the need for such balance because who really needs to see what is wrong when things are going right and the only legitimate concern is the president's sex life. Applying Bakhtin's concepts of the carnivalesque to TBL, Paul Martin and Valerie Renegar observe,

[I]n the late 1990s, the United States was enjoying a period of economic and social prosperity.... Consequently, most Americans were not receptive to social critiques that TBL had to offer. However, in the intervening years, the cultural landscape has shifted in several important areas. With a flagging economy, an extended and bloody war with Iraq, and the terrorist attacks of September 11, the United States has increasingly become a place where the mainstream media tends to legitimate only official points of view and political dissent is unpopular. The latter tends to be "swallowed by the big official spin" (Griffen 279), creating a void in popular critical discourse. With this void begging to be filled by those left voiceless and powerless, The Big Lebowski has become even more relevant today.

It is hardly coincidental then that the first Lebowski Fest, very much a carnivalesque event, was held on October $12^{\text {th }}, 2002$ at Fellowship Lanes in Louisville, Kentucky. Although "this inaugural year was a bit tame," as "Fellowship Lanes is a Baptist run bowling alley which didn't allow drinking or cussing" ("Lebowski Fest"), the very fact that this less than liberal state has become home to an annual event celebrating the Coens' unruly creation proves that, to quote Walter quoting Theodor Herzl, "if you will it, it is no dream" $(T B L)$. In the parlance of the capitalist Lebowski, over time, TBL has met challenges, bested competitors (none of the 1990s slacker movies can boast this amount of attention in the age of technology), overcome obstacles (cf. TBL), and made the social and cultural opposites meet within and without its historical timeframe, while eluding easy classification all along.

$T B L$ spaces out of time on many levels and in many directions, almost as surrealistically as the knocked out Dude does flying over the Los Angeles nightscape in the first dream sequence. The location of TBL marks, reflects and coheres with the film's cultural marginality, oddities and rejection of narrative discipline, which might help throw some more light on 
the shift in TBL's status. At the outset of the story, the Stranger muses in his Texan drawl,

A way out west there was a fella, ... fella by the name of Jeff Lebowski. ... This Lebowski, he called himself the Dude. Now, Dude, that's a name no one would self-apply where I come from. But then, there was a lot about the Dude that didn't make a whole lot of sense to me. And a lot about where he lived, likewise. But then again, maybe that's why I found the place s'durned innarestin'. (Coen and Coen 3)

The Stranger comments on the regional and cultural differences of his country, pointing out that the Dude and his place of residence intrigue him because they both elude his Southern logic. After this introduction, according to the script's action description, "the smoggy vastness of Los Angeles [at twilight] stretches out before us" (Coen and Coen 3), and the Stranger adds, "They call Los Angeles the City of Angels. I didn't find it to be that exactly, but I'll allow it as there are some nice folks there" (Coen and Coen 3). The Stranger represents the American invention of "that most mythic individual hero, the cowboy, who again and again saves a society he can never completely fit into" (Bellah at al. 145). Less solemn in nature than Will Kane and with a Dude-like attitude towards his role as narrator, this cowboy, a literal American "Stranger" in L.A., is just such an individual to whom city life does not "make a whole lot of sense" and for whom his home prairie territory promises openness and freedom, in contrast to "the massive electrical L.A. grid that the film's opening sequence lingers on" (Ashe 47). With his Southern accent and cowboy gear, the narrator stands out in the bowling alley, and yet, when midway through the story the Dude casually compliments the Stranger's outfit, the city setting suddenly becomes more complimentary as well, and the Dude, in his stretched-out sweater, might be perceived as a reluctant cowboy-type himself.

Located between the Mojave desert and the Pacific ocean, Los Angeles, both metaphorically and geographically, traps the free flow of the American West and, as a profit-hungry and economically exploitative metropolis, "presages the end of individual autonomy as a primary feature of American life" (Ashe 47). And yet, with its most famous district, Hollywood, responsible for popularizing the cowboy image and, thus, enhancing the mythic image of American individualism and self-reliance, as well as with "more artists, writers, filmmakers, actors, dancers and musicians living and working [there] than [in] any other city at any time in the history of civilization" ("Only"), the City of Angels also poses as an almost God-like place, providing unlimited creative opportunities for various in- 
dividuals, many of whom happen to be as outlandish in their lifestyles as the Coens' artistic output and, thus, frequently referred to as "freaks." One of the most succinct literary references rendering the cultural ambiance of this city, a place uninhibited by Puritan heritage, comes from Hunter S. Thompson's Fear and Loathing in Las Vegas: A Savage Journey to the Heart of the American Dream. Halfway through their drug-infused Las Vegas escapade, having violated most social norms for the sake of testing and exposing the downsides of the American Dream, Raoul Duke, based on Thompson himself, decides to decline his Samoan attorney's telegram invitation to report to the Dunes Hotel for more abuse of everything that can be abused, as he thinks he "pushed" his "luck about as far as it was going to carry [him] in this town ... all the way out to the edge" (78). Consequently, he plans his escape back to L.A.,

There is only one road to L.A.-US Interstate 15 , a straight run with no backroads or alternate routes, just a flat-out high-speed burn through Baker and Barstow and Berdoo and then on the Hollywood Freeway straight into frantic oblivion: safety, obscurity, just another freak in the Freak Kingdom. (Hunter S. Thompson 83)

While both cities could easily compete for the American Dream myth capital, Duke, with whom the Dude incidentally has a lot in common, finds Los Angeles, even at the peak of its 1970s racial tensions, to be a place where someone like him feels relatively secure, possibly because, unlike Las Vegas, Los Angeles tends to be less "relentlessly middle-class, middleincome, and middle-aged" (cf. Whissen 90), which, from the standpoint of unbridled, financially broke individuals unconcerned with time, like Duke or the Dude, is definitely a good thing, allowing such outsiders not to have too much money and ambition, and yet still enjoy life on their own terms in this predominantly "two-class [region] of haves and havenots" (Whissen 90). Ambition, the pressure for success and money are there but so is the choice not to do too much or to do things weirdly and differently. Reporting back on Lebowski Fest West, which finally took place in L.A. in 2005, a LEO weekly journalist observes that in spite of the discomforting attention the fest staff were getting from the cameras documenting the event, the commotion and interest "still seemed like nothing to L.A.- - city whose smoggy breath continually warps your horizon as fast as it cranks out more freaks to draw the attention away from you” (Titan). Trapped between two geographical extremes, yet expanding over an impressively vast area with several independent cities attached to or engulfed by it, Los Angeles liberally allows over-the-top otherness as much as obliterates it, only to spout out more bizarreness. Unlike TBL at 
the time of its original release, the L.A. Lebowski Fest of 2005 managed to make a mark in the region, selling out entirely for its two-day celebration and disappointing "the countless people who planned on attending but were caught unaware of the power of the Lebowskifest" (Titan). The Entertainment Capital of the World clearly underestimated the impact of its own marginal creation which did not benefit the city's economy in 1998 when it was born, but, like Frankenstein's creature, came back to claim its position.

Just as $T B L$ stitches together genres and "suggests . . laid-back connections between more or less disparate phenomena" (Comentale and Jaffe 5) (e.g. the Dude's Wizard of Oz-like pair of bowling shoes handed to him by a Saddam look-alike, the wicked wizard of Western Asia, in the second dream sequence), Los Angeles stitches together a unique variety of cultures from within and without America. After having been captured from the Mexicans by US forces in 1846, this west-coast area speedily became an American "bastion of middle-class whiteness" (Avila 230), only to renegotiate these conditions and rebalance its predominantly white population at the end of the twentieth century:

Since 1970, the vast influx of immigrant populations into Southern California has transformed the region ... into a Third World citadel. In 1970, 71 percent of Los Angeles County's population was non-Hispanic white or Anglo, and the remaining 29 percent of the population was divided among Latinos (15 percent), African Americans (11 percent), and Asian/Pacific Islanders (3 percent). By 1980, the non-Hispanic white population had dropped to 53 percent, and ten years later it had fallen further to 41 percent.... By 1990, Latinos comprised 36 percent of the city's population; African Americans and Asians constituted 11 percent, respectively. Today's Los Angeles ranks among the most diverse urban regions in the world and the city once heralded as the "nation's white spot" now mirrors the polyglot diversity that defines the city and even its past. (Avila 230)

Such cultural and political changes might also partially account for $T B L$ 's rather moderate reception in 1998. In order "to preserve white hegemony," "[i]n the 1990s, California voters passed a series of measures that targeted immigrant groups and racial minorities," for instance Proposition 13 , which "drastically reduced property taxes at the expense of public services such as schools, libraries, and police and fire protection, services that racial minorities have been increasingly forced to rely on" (Avila 232, 233). The threat that speedily growing non-white minorities were perceived to pose to the whites found its reflection in the region's political and cultural output: 
One year after the end of the Reagan-Bush era and on the heels of the Rodney King uprising of 1992, the film Falling Down engendered controversy among national audiences for its neonoir portrayal of the white man's identity crisis in contemporary Los Angeles. "D-Fens, " an unemployed engineer suffering a nervous breakdown, begins a killing spree as he walks from downtown Los Angeles to the beach. In the tradition of noir's white male antihero, D-Fens trudges through the racialized milieu of the city, attacking a Korean market, a fast-food outlet, a Chicano gang, and a neo-Nazi. The city that once resonated with compelling expressions of suburban whiteness is now alien territory for D-Fens, an inhospitable non-Anglo landscape that renders white male identity obsolete. (Avila 234)

Falling Down became a box office hit because the misunderstood protagonist is a military type who, like a lonely cowboy, fights violence in search of justice at the time of white flight. Six years later, with an even greater upsurge in immigration and powerful cultural changes in the region, the Coens' neonoir "Western at the limit of the West" (Comentale and Jaffe 6) might have seemed oddly out of place. If D-Fens aka William Foster (Michael Douglas) indicates "the fin de siècle crisis of white male identity" (Avila 234), the image of an unemployed, family-shunning hippie could hardly have helped enhance this identity in 1998, and, thus, might not have initially resonated with white male Americans, or their wives. Moreover, in spite of lacking aggression himself, the Dude's character, with his 1960s pacifist mind-set and liberal attitude even towards the nihilists who burn his car, might, by association and quite ironically, bring to mind more radical and culturally resonant acts of violence which L.A. gave vent to at a time of rapidly increasing immigration and the civil rights movement, such as Robert Kennedy's 1968 assassination at the Ambassador Hotel, "the gruesome spectacle of the Manson family" or the 1970 killing of Rubén Salazar, who was "held up as a martyr in the struggle against Chicano oppression" (Avila 227). The majority of whites in Southern California were prone to blaming the non-white immigrants, angry minorities and the civil rights activists for the lack of morals in the area and "for obstructing their path to realizing the suburban good life" in the 1970s and 1980s (Avila 227).

Thus, it is hardly surprising that in the 1990s a Caucasian, confronting a city filled with violence and social deviants worse than him, and wandering through L.A. with a bagful of weapons reclaimed from a revenge-seeking Latino gang, mastered more sympathy from the audience nationwide than a pot-smoking dropout who drives around L.A. for recreation. Eventually, however, in this contest of two cowboy-like types, the Dude wins without drawing any weapons, because, unlike unstable 
white-collar D-Fens, who also used to be prone to bouts of aggression as a family man, the Dude represents a consistent, laid-back, unemployed single individual, whose lack of typically masculine/military behaviour and disregard for forced male responsibilities offer an alternative to the craziness and violence of L.A. that also resonated with males all over the country, who, at the beginning of the twenty-first century, must have felt not only the crisis of identity resulting from the unprecedented increase in women's rights and power, but were also probably eager to avoid the post $9 / 11$ military commotion and drop out of yet another imperialistic US intervention waged, in order to, among other things, benefit the likes of "the other Jeffrey Lebowski, the millionaire" (TBL). This does not mean, however, that the Coens' unorthodox homage to the Western genre and to Los Angeles "as natural extension of the American frontier" (Comentale 228) and as the setting of multiple noir classics is devoid of violence and demand for justice, the two necessary profit-harvesting ingredients in most products of the Dream Factory. The acts of aggression and angst in $T B L$ include, among other things, frequent references to the Vietnam War, Walter's angry outbursts triggered by almost everyone and everything, a gun in the bowling alley, a disturbing dance number by Jesus Quintana-allegedly an ex-pederast with a record, a severed toe and a bitten-off ear, repeated threats of genital mutilation, a mug thrown at the Dude's forehead by the sadistic police chief of Malibu-"a real reactionary" (TBL), the accidental shooting, untimely stealing and premeditated burning of the Dude's car, and, last but not least, Donny's death caused by trauma experienced during the fight between Walter and the alleged kidnappers of Bunny Lebowski. All this violence, simultaneously suffused and sharpened by the Coens' stylized cinematography, is as scary as it is funny, calling for a hero who feels at home in the City of Angels, this "bizarre universe, a shimmering America beyond America" (Comentale 228), because only such an individual could have developed enough immunity to survive all the dangers and anxiety that such a mixture of weirdness, surrealism and aggression are bound to cause to an average man. As Edward P. Comentale observes, the Dude, definitely "a man for his time and place," remains cowboy-style righteous, albeit unarmed and unaggressive,

[T] he film presents the Dude as representative of a lost mode of living, a defender of the old easygoing ways against all manner of big city cons. A drifter, a dropout, a man extremely slow to provoke, the Dude nonetheless serves to uphold a moral code in a battle against forces that are awkwardly juxtaposed, but undeniably modern: big business, big government, fluxus feminists, and German nihilists. (230) 
Although at the time of his debut "a lot about the Dude didn't make a whole lot of sense" to Americans, "[a]nd a lot about where he lived, likewise," they eventually found both "durned innarestin." A "deadbeat" might seem like mediocre hero material, but he can still "uphold a moral code" without compromising his simple ideals of pacifism and leisure, ideals which many were finally able to recognize and embrace as an antidote to the aggression-fuelled and war-oriented American life at the beginning of the twenty-first century. Geographically and culturally positioned at the edge of the country's landscape, Los Angeles visually enhances the adventures of the Dude, who, on the whole, feels comfortable in its vastness and sustains his presence, his "royal we" (TBL), equally well in the Pasadena mansion of his namesake and in his own frequently invaded and thrashed simple abode. The city's impressive night-time overview, the characteristic Googie architecture, which became an integral part of US scenery in the 1950s and early 1960s (Martin-Jones 220), and "the everyday feel of [its climate] from a low-rent perspective" (Rosenbaum) feature as culturally recognizable trademarks, while the Dude's lack of aggression exposes and balances the city's gratuitous violence, giving the ultimate frontier myth a fresh twist.

While basic information has been provided about the film's main protagonist and how he might have contributed to the movie's delayed success, little has been said about the other characters, each of whom might provide additional insight into what has made TBL a cultural icon regardless of its otherness and initial failure. Since each character provides enough material for at least a separate essay, they hardly fit into these concluding remarks. Yet, it must be mentioned that the critics in 1998 were dissatisfied not only with the movie's narrative structure but also with the characters. Jonathan Rosenbaum seemed particularly disappointed, piling up accusation upon accusation: "the Coen brothers ... lin[e] up a succession of autonomous freaks"; "All that The Big Lebowski really cares about is the nightmarishness of 90 s Los Angeles and the way a couple of dysfunctional 70s types endure it"; "The Dude and Sobchak begin as caricatures ...., but they're allowed to grow into something deeper, if only because the humanist economy of the Coens' surrealist vaudeville allows for a couple of human beings within the tapestry of freaks," while "[the arbitrary narrative] reduces everyone else in the movie to a parade of satirical cartoons" (Rosenbaum). Undoubtedly, as Roger Ebert more favourably points out, "Los Angeles in this film is a zoo of peculiar characters" (Ebert), featuring, among others, the Dude's bowling companion Walter Sobchak (John Goodman), the Vietnam veteran connecting the Vietnam War with literally everything; the Dude's landlord Marty (Jack Kehler), an aspiring performer whose "dance quintet" and costume can only be out-weirded by the tight purple costume 
and slow-motion dance of the Dude's bowling rival Jesus Quintana (John Turturro); and, last but not least, the Dude's "special lady friend," Maude Lebowski (Julianne Moore), the other Lebowski's artsy daughter, who "covers her body with paint and hurls herself through the air in a leather harness" (Ebert), and whom Rosenbaum sees as "a nasty parody of a feminist artist," conveniently ignoring the fact that the financially and artistically independent Maude actually figures as the titular Big Lebowski (Julianne Moore observes that while Maude is "almost beyond pretentious," "she's [also] got all the power" and "the Dude respects Maude for what she is and what she does," which she reciprocates [Green et al. 38]). The Coens' choice "to lin[e] up a succession of autonomous freaks" in TBL serves a purpose that Rosenbaum and many other critics failed to appreciate at the time of the film's theatrical release. While certain characters such as the nihilists could be classified as "dysfunctional types" in the sense of being a threat to non-violent members of society, others, such as, for instance, the Dude's quirky landlord or even Walter, help redefine "freakishness" as a term denoting choice, openness, freedom, security, and, last but not least, a type of unquestionable achievement which does not require one to compromise their original values.

Born in Louisville, Kentucky, Hunter S. Thompson aka Raoul Duke would certainly embrace the Coens' "tapestry of freaks," and so would Dylan Moran, an Irish actor and stand-up comedian, who in his 2006 show quips: "Arnold Schwarzenegger is the governor of California. There is a perfectly ordinary English sentence. How did that happen? Do you know how that happened? 'Cause I tell you .... He got there by lifting things" (Moran). Sarcastic as it is, Moran's remark, however, pays tribute to the Golden State, implicitly contrasting California's cultural flexibility with the more traditional, not to say rigid, culture of, for instance, Great Britain. Although no longer governor as of January 2011, Schwarzenegger has raised the bar for the unusual in the region yet another notch, simultaneously redefining his own long-lasting American Dream. Although all the Dude ever lifts is a bowling ball and glasses of White Russian, TBL's shift from a commercially and critically marginal production to a culturally significant yet inherently offbeat phenomenon measures up to the from-rags-to-riches life story of the Austrian bodybuilder-turned-Mr. Universe-turned-actor-turned-politician, who, incidentally, after moving to California trained at Gold's Gym in Venice, Los Angeles, which is where the Dude dwells. The number of both bizarre and classic cultural connections one can draw in relation to $T B L$ is endless, twisted and surprisingly gratifying, though the real pleasure lies in just enjoying the ride. As Ebert rightly observes, “The Coen brothers' The Big Leborwsi is a genial, shambling comedy [which] should come with a warning like the one Mark Twain attached to Huckleberry Finn: 'Persons attempting 
to find a plot in it will be shot'” (Ebert). And yet, just like in Twain's unnecessarily censored classic, there is nothing incidental in the Coens' film, a pertinent example of which can be found in the movie's constant play on "the Dude's trademark verb-to abide-... contrasted with Lebowski's - to achieve" (Comentale and Jaffe 20), a distinction which serves to defend the Dude's lazy lifestyle against the unrelenting Puritan work ethic. Because even if the Dude is a lazy man and a relic of his recent rebellious past, and, thus, the utmost failure among the 1990s' slackers, in time he has proven that, in the parlance of the Port Huron Statement, the famous American independence does not have to equal "egotistic individualism" or military involvement- "the object is not to have one's way so much as it is to have a way that is one's own" ("Port Huron"). Finally, against The Guardian critic's prediction, The Big Lebowski did win a prize, the 1998 Golden Aries for Best Foreign Film, awarded, coincidentally yet more than appropriately, by the Russian Guild of Film Critics. To use the Dude's favourite qualifier: How "far-out" is that? Enough to repeatedly toast The Big Leborwski's rise from a box office bomb to a nation-wide cultural event with the Dude's favourite drink.

\section{WORKS CITED}

Ashe, Fred. "The Really Big Sleep: Jeffrey Lebowski as the Second Coming of Rip Van Winkle.” The Year's Work in Lebowski Studies. Ed. Edward P. Comentale and Aaron Jaffe. Bloomington, IN: Indiana UP, 2009. 41-57. Print.

Avila, Eric. Popular Culture in the Age of White Flight: Fear and Fantasy in Suburban Los Angeles. Berkeley: U of California P, 2004. Print.

Bellah, Robert N., et al. Habits of the Heart: Individualism and Commitment in American Life. Berkeley: U of California P, 1996. Print.

Big Leboreski, The. Dir. Joel Coen. Perf. Jeff Bridges, John Goodman and Julianne Moore. 1998. DVD. Universal, 2003.

"Big Lebowski." Rev. of The Big Lebowski. Guardian.co.uk. Guardian 24 Apr. 1998. Web. 27 June 2011.

Coen, Ethan, and Joel Coen. The Big Lebowski. [Screenplay]. London: Faber, 1998. Print.

Comentale, Edward P. “'I'll Keep Rolling Along': Some Notes on Singing Cowboys and Bowling Alleys in The Big Lebowski." The Year's Work in Lebowski Studies. Ed. Edward P. Comentale and Aaron Jaffe. Bloomington, IN: Indiana UP, 2009. 228-51. Print.

Comentale, Edward P., and Aaron Jaffe. "Introduction." The Year's Work in Leboreski Studies. Ed. Edward P. Comentale and Aaron Jaffe. Bloomington, IN: Indiana UP, 2009. 1-37. Print. 
"Dudeism." Dudeism.com. 2010. Web. 8 Oct. 2011.

Ebert, Roger. "The Big Lebowski." Rogerebert.com. Chicago SunTimes 6 Mar. 1998. Web. 25 June 2011.

Glazer, Nathan. "Individualism and Equality in the United States." Making America: The Society and Culture of the United States. Ed. Luther S. Luedtke. Washington, D.C.: US Information Agency, 1987. 226-40. Print.

Green, Bill, et al. I'm a Lebowski, You're a Lebowski: Life, the Big Leboreski and What Have You. New York: Bloomsbury, 2007. Print.

Hoggard, Liz. "Get with the Dude's Vibe: The Big Lebowski Has, Like, Its Own Festival? Cool, Man.” Guardian.co.uk. Observer 22 July 2007. Web. 30 July 2011.

Howe, Desson. “'Big Lebowski': Rollin' a Strike.” Washingtonpost. com. Washington Post 6 Mar. 1998. Web. 25 July 2011.

Howell, Peter. “Coens' Latest Doesn't Hold Together: The Big Leboreski Is More Sprawling than Large.” Thestar.com. Toronto Star 19 Jan. 1998. Web. 25 June 2011.

Irving, Washington. "Rip Van Winkle." The Norton Anthology of American Literature. Ed. Nina Baym. New York: Norton, 2003. 980-92. Print.

Kehr, Dave. “Coen Brothers' Latest Is a Big Letdownski Comedy about Druggie Bowler Strikes Out and Its Tired Film Noir Plot Is a Turkey.” NYDailyNeres.com. Daily News 6 Mar. 1998. Web. 25 June 2011.

"Lebowski Fest." Lebowskifest.com. 2011. Web. 2 July 2011.

Lutz, Tom. Doing Nothing: A History of Loafers, Loungers, Slackers, and Bums in America. New York: Farrar, 2006. Print.

Martin-Jones, David. "No Literal Connection: Mass Commodification, U.S. Militarism, and the Oil Industry in The Big Leboreski." The Year's Work in Leboreski Studies. Ed. Edward P. Comentale and Aaron Jaffe. Bloomington, IN: Indiana UP, 2009. 203-27. Print.

Martin, Paul, and Valerie Renegar. "The Man for His Time': The Big Leborwsi as Carnivalesque Social Critique.” Communication Studies 58.3 (2007): 299+.questia.com. Gale Group, 2007. Web. 6 Mar. 2011.

Moran, Dylan. Dylan Moran Live: Like, Totally. Universal Pictures UK, 2006. DVD.

"Only in LA." University of Southern California. USC Stevens Institute for Innovation. 2001. Web. 25 June 2011.

"Port Huron Statement of the Students for a Democratic Society, 1962.” Courtesy Office of Sen. Tom Hayden. H-net.org. Web. 25 July 2011.

Rosenbaum, Jonathan. "L.A. Residential.” Chicagoreader.com. Chicago Reader 5 Mar. 1998. Web. 28 June 2011.

"Seattle Liberation Front." Free Online Encyclopedia of Washington State History. HistoryLink.org. 2010. Web. 25 June 2011. 
Titan, Ray. "Mark it Awesome, Dude: Lebowskifest Rolls in L.A. (and That's Not Louisville Area).” GoErie.com. GoErie, 30 Mar. 2005. Web. 7 July 2011.

Thompson, Hunter S. Fear and Loathing in Las Vegas. London: Flamingo, 1998. Print.

Thompson, Stacey. "The Dude and the New Left." The Year's Work in Lebowski Studies. Ed. Edward P. Comentale and Aaron Jaffe. Bloomington, IN: Indiana UP, 2009. 124-48. Print.

Turran, Kenneth. Rev. of The Big Lebowski. Rogerebert.com. L.A. Times 6 Mar. 1998. Web. 27 June 2011.

Whissen, Thomas Reed. Classic Cult Fiction: A Companion to Popular Cult Literature. New York: Greenwood, 1992. Print. 